\title{
Mosses as Bioindicators of Heavy Metal Air Pollution in the Lockdown Period Adopted to Cope with the COVID-19 Pandemic
}

\author{
Nikita Yushin ${ }^{1}$, Omari Chaligava ${ }^{1,2}$, Inga Zinicovscaia ${ }^{1,3, *}$, Konstantin Vergel ${ }^{1}$ and \\ Dmitrii Grozdov ${ }^{1}$ \\ 1 Joint Institute for Nuclear Research, Joliot-Curie 6, 141980 Dubna, Russia; ynik_62@mail.ru (N.Y.); \\ omar.chaligava@ens.tsu.edu.ge (O.C.); verkn@mail.ru (K.V.); dsgrozdov@rambler.ru (D.G.) \\ 2 Faculty of Exact and Natural Science, Ivane Javakhishvili Tbilisi State University, Chavchavadze ave. 3, \\ 0179 Tbilisi, Georgia \\ 3 Horia Hulubei National Institute for R\&D in Physics and Nuclear Engineering, 30 Reactorului, \\ MG-6 Bucharest-Magurele, Romania \\ * Correspondence: zinikovskaia@mail.ru; Tel.: +7-496-216-5609
}

Received: 9 October 2020; Accepted: 1 November 2020; Published: 3 November 2020

\begin{abstract}
The coronavirus disease, COVID-19, has had a great negative impact on human health and economies all over the world. To prevent the spread of infection in many countries, including the Russian Federation, public life was restricted. To assess the impact of the taken actions on air quality in the Moscow region, in June 2020, mosses Pleurosium shreberi were collected at 19 sites considered as polluted in the territory of the region based on the results of the previous moss surveys. The content of $\mathrm{Cd}, \mathrm{Cr}, \mathrm{Cu}, \mathrm{Fe}, \mathrm{Ni}$, and $\mathrm{Pb}$ in the moss samples was determined using atomic absorption spectrometry. The obtained values were compared with the data from the moss survey performed in June 2019 at the same sampling sites. Compared to 2019 data, the Cd content in moss samples decreased by $2-46 \%$, while the iron content increased by $3-127 \%$. The content of $\mathrm{Cu}, \mathrm{Ni}$, and $\mathrm{Pb}$ in mosses decreased at most sampling sites, except for the eastern part of the Moscow region, where a considerable number of engineering and metal processing plants operate. The stay-at-home order issued in the Moscow region resulted in a reduction of vehicle emissions affecting air quality, while the negative impact of the industrial sector remained at the level of 2019 or even increased.
\end{abstract}

Keywords: COVID-19; air pollution; metals; industry; moss survey; biomonitoring

\section{Introduction}

On March 11, 2020, the World Health Organization declared COVID-19 as a global pandemic [1]. On March 12, based on a decree of the Government of the Moscow region, a self-isolation regime was introduced. According to the official decision, only essential services such as healthcare, logistics, food supply, public transport, and industrial enterprises due to technical reasons did not cease to operate. A significant part of the regular national and international flights and train services was cancelled. Since the majority of the population switched to remote working, the number of vehicles has dropped significantly.

New rules adopted in many countries to help slow the spread of COVID-19 resulted in a decrease in the negative impact on the environment in some regions of the world [2]. Nadzir et al. [3] measured the concentrations of $\mathrm{CO}, \mathrm{PM}_{2.5}$, and $\mathrm{PM}_{10}$ in Malaysia and observed that the concentration of pollutants declined significantly, by $\approx 20$ to $60 \%$, during the Control Order in Malaysia (MCO) days at most studied locations. At the same time, in Kota Damansara, the level of pollutants significantly increased due to local anthropogenic activity. COVID-19 resulted in a worldwide decrease in the concentration of $\mathrm{CO}_{2}$ 
in March 2020 by 7\% in comparison with the monthly concentration in 2019 [4]. In three Chinese cities (Chongqing, Luzhou, and Chengdu) concentrations of $\mathrm{PM}_{2.5}, \mathrm{PM}_{10}, \mathrm{SO}_{2}, \mathrm{CO}$, and $\mathrm{NO}_{2}$ in February 2020 were lower by $17.9 \%-62.1 \%$ than the values determined in February 2017-2019 [5]. In three other cities in China (Wuhan, Jingmen, and Enshi) concentrations of the abovementioned pollutants measured in February 2020 declined by $27.9 \%-61.4 \%$ compared to February 2017-2019. At the same time, in the period of January-March 2020, an increase of $\mathrm{O}_{3}$ concentration of up to $15 \%$ was noticed [6]. In Turkey, the concentrations of $\mathrm{PM}_{10}$ and $\mathrm{NO}_{2}$ in 2016 and 2020 were compared, and no significant difference in $\mathrm{PM}_{10}$ concentrations was observed. In the after-lockdown period, the $\mathrm{NO}_{2}$ concentrations were lowered by $11.8 \%$ [7]. A decrease in the $\mathrm{PM}_{2.5}$ concentration in Wuhan, Daegu, and Tokyo by $29.9 \%, 20.9 \%$, and $3.6 \%$, respectively, took place after one month of COVID-related restrictions. The concentration of $\mathrm{NO}_{2}$ also declined in all three cities, with the most pronounced decrease being by $53.2 \%$ in Wuhan [2]. In Brazil, a remarkable decrease in $\mathrm{CO}$ and $\mathrm{NO}_{2}$ concentrations was observed during the lockdown period [8].

PM contains various metals, including some elements recognized as human carcinogens. Sources of metals in the atmosphere can be natural: soil dust, volcano eruptions, and forest fires, or they can be anthropogenic, which include road traffic, industry, and thermal power plants [9]. It is often difficult to conduct measurements of concentrations of atmospheric metals over large territories. Passive moss biomonitoring proved to be a suitable technique to study the spatial distribution of metals over the large territories [10]. This technique is well recognized and widely applied in many European countries [11]. Although data obtained using moss biomonitors do not correspond to the direct quantitative measurement of metal deposition [12], this information is very useful for regions where it is difficult to obtain official data related to air pollution. In the Moscow region, moss survey studies were performed in 2004 [13], 2014 [14], and 2019 (data not yet published).

The aim of the present study was to find out whether moss can be used as a tool to assess the impact of the restrictions due to the lockdown imposed to face the pandemic emergency on air quality in a relatively short time (2.5 mounts). For this purpose, the data obtained for moss samples collected in the Moscow region in June 2020 were compared with the data obtained in 2019 for the same collection sites.

\section{Experiments}

\subsection{Study Area and Sampling}

The Moscow region, which is a subject of the Russian Federation, is one of the most densely populated and industrially developed regions of the country [14]. The Moscow region can be considered the economic core of the country, with about $70 \%$ of Russia's financial wealth concentrated here. It is located in the center of railway and air networks, reaching Transcaucasia, Central Asia, and the Pacific, and it is connected by rivers and canals to the Baltic, White, Azov, Black, and Caspian Seas [15]. In the center of the region is Moscow, the capital of the Russian Federation, and the most important industrial city, transportation hub, educational and cultural center of the region [13,15]. The industrial sector of the Moscow region includes metallurgical, oil refining, mechanical engineering, food, energy, and chemical enterprises [14]. The main industrial centers in the Moscow region are: Krasnogorsk, Lyubertsy, Mytishchi, Klin, Noginsk, Pavlovsky Posad, Voskresensk, Kolomna, Dmitrov, Klin, Elektrostal, Balashikha, and Sergiyev Posad.

In 2019 and 2020, moss Pleurosium shreberi was collected on the sheared tree bark. Moss sampling was performed in June 2019 and June 2020 at 19 sampling sites (Figure 1) in accordance with [16]. The selection of the sampling sites in 2020 was based on the moss survey data obtained in 2019 (analyzed but not yet published). Moss samples were collected at sites with the highest metal concentrations in 2019. After collection, samples were cleaned of soil particles and other contaminants. The upper $3-4 \mathrm{~cm}$ of green and green-brown shoots from the top of the moss were separated and dried at $105^{\circ} \mathrm{C}$ to constant weight. For analysis, approximately $0.2 \mathrm{~g}$ of moss was placed in a Teflon vessel and treated 
with $2 \mathrm{~mL}$ of concentrated nitric acid and $1 \mathrm{~mL}$ of hydrogen peroxide. The Teflon vessels were put into a microwave digestion system (Mars; CEM, USA) for complete digestion. Digestion was performed in two steps: (1) ramp: temperature $180^{\circ} \mathrm{C}$, time $15 \mathrm{~min}$, power $400 \mathrm{~W}$, and pressure $20 \mathrm{bar}$; (2) hold: temperature $160{ }^{\circ} \mathrm{C}$, time $10 \mathrm{~min}$, power $400 \mathrm{~W}$, and pressure 20 bar. Digests were quantitatively transferred to $100-\mathrm{mL}$ calibrated flasks and made up to the volume with bidistilled water.

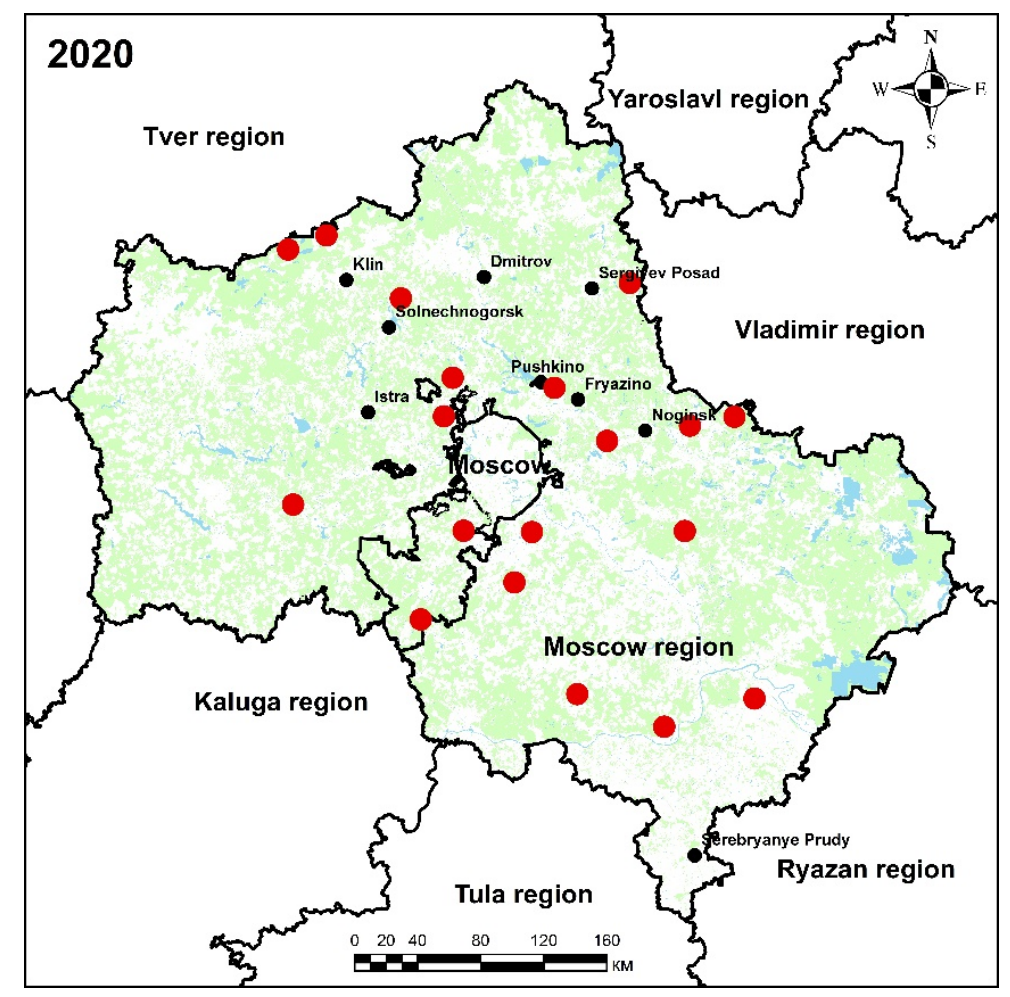

Figure 1. Sampling map (in 2019 and 2020 samples were collected in the same sampling sites).

\subsection{Chemical Analysis}

The content of $\mathrm{Cd}, \mathrm{Cu}, \mathrm{Pb}, \mathrm{Cr}, \mathrm{Ni}, \mathrm{Fe}, \mathrm{V}$, and $\mathrm{Sb}$ in the moss samples was determined by means of atomic absorption spectrometry using a Thermo Scientific ${ }^{\mathrm{TM}}$ iCE $^{\mathrm{TM}} 3400$ AA spectrometer (Thermo Scientific, Waltham, MA, USA) with electrothermal (graphite furnace) atomization. Stock solutions (AAS standard solution; Merck, Germany) with metal concentrations of $1 \mathrm{~g} / \mathrm{L}$ were used to prepare calibration solutions. The National Institute of Standards and Technology (NIST) reference materials 1570a (Trace Elements in Spinach Leaves) and 1575a (Pine Needles) were used to ensure the quality control of measurements. The difference between determined and certified values did not exceed $5 \%$.

\subsection{Data Processing}

Statistical analysis of the data was done using Excel 2016 (Microsoft, Redmond, Washington, USA) and IBM SPSS software (IBM, Armonk, New York, USA). The Wilcoxon signed-rank test [17] was applied to define differences between the values obtained in 2019 and 2020. The ArcGis 10.6 software (Esri, Redlands, California, USA) was used to build maps showing the spatial distribution of elements.

To quantify the anthropogenic influence on the environment, several indices were calculated, such as the contamination factor (CF), the Geo-accumulation Index $\left(\mathrm{I}_{\text {geo }}\right)$, and the pollution load index (PLI).

The contamination factor $\mathrm{CF}$ is defined as:

$$
\mathrm{CF}=\frac{\mathrm{C}_{\mathrm{m}}}{\mathrm{C}_{\mathrm{b}}}
$$


where $C_{m}$ is the measured content of the metal at any given site and $C_{b}$ is the background level for that metal [18].

CF $<1$ no contamination; $1-2$ suspected; $2-3.5$ slight; $3.5-8$ moderate; $8-27$ severe; and $>27$ extreme [19].

The index of geo-accumulation, $\mathrm{I}_{\mathrm{geo}}$, was calculated using the following formula:

$$
\mathrm{C}_{\mathrm{F}}=\frac{\mathrm{C}_{\mathrm{M}}}{1.5 \mathrm{C}_{\mathrm{B}}}
$$

where $\frac{C_{M}}{C_{B}}$ is the contamination factor. The factor of 1.5 is introduced to minimize the effect of possible variations in the background [20].

I geo $_{20}$ no contamination; $0-1$ slightly polluted; 1-2 moderately polluted; 2-3 moderately to severely polluted; $3-4$ severely polluted; $4-5$ severely to extremely polluted; and $\mathrm{I}_{\text {geo }}>5$ extremely polluted [21].

The PLI represents the nth order geometric mean of the entire set of CF regarding the contaminating elements as follows:

$$
\text { PLI }=\sqrt[n]{\prod_{i=1}^{n} C_{F, i}}
$$

where $\mathrm{n}$ is the total number of contaminating elements.

PLI $<1$ (non polluted); $1 \leq$ PLI $<2$ (slight polluted); $2 \leq$ PLI $<3$ (moderately polluted); PLI $<3$ (highly polluted) [22].

\section{Results and Discussion}

Eight elements were determined in the analyzed moss samples using atomic absorption spectrometry (AAS). Since the concentrations of $\mathrm{V}$ and $\mathrm{Sb}$ were below the detection limits, these elements were excluded from further discussion. The results of the statistical analysis for the analyzed elements in 2019 and 2020 are presented in Table 1.

Table 1. Descriptive statistics of results for moss samples collected in 2019 and 2020 (in mg/kg dry

\begin{tabular}{|c|c|c|c|c|c|c|c|c|}
\hline Element & Year & Range & Md & Mean \pm St. Dev & Q1 & Q3 & $\begin{array}{l}\text { CV } \\
(\%)\end{array}$ & $p$ \\
\hline \multirow{2}{*}{ Cd } & 2019 & $0.11-0.64$ & 0.30 & $0.34 \pm 0.14$ & 0.23 & 0.41 & 41.9 & \multirow{2}{*}{$<0.05$} \\
\hline & 2020 & $0.14-0.52$ & 0.24 & $0.26 \pm 0.09$ & 0.22 & 0.30 & 33.9 & \\
\hline \multirow{2}{*}{$\mathrm{Pb}$} & 2019 & $1.71-17.2$ & 4.41 & $5.62 \pm 3.45$ & 3.80 & 7.02 & 61.4 & \multirow{2}{*}{$>0.05$} \\
\hline & 2020 & $1.79-13.6$ & 4.60 & $5.31 \pm 3.14$ & 3.21 & 6.26 & 59.2 & \\
\hline \multirow{2}{*}{$\mathrm{Cu}$} & 2019 & $6.38-21$ & 8.98 & $10.3 \pm 3.93$ & 7.29 & 12.9 & 38.3 & \multirow{2}{*}{$<0.05$} \\
\hline & 2020 & $4.72-15.8$ & 7.76 & $8.8 \pm 3.18$ & 6.64 & 9.36 & 36.3 & \\
\hline \multirow{2}{*}{$\mathrm{Cr}$} & 2019 & $1.1-3.09$ & 1.98 & $1.87 \pm 0.58$ & 1.32 & 2.16 & 30.8 & \multirow{2}{*}{$>0.05$} \\
\hline & 2020 & $1.01-4.29$ & 1.98 & $2 \pm 0.75$ & 1.46 & 2.18 & 37.6 & \\
\hline \multirow{2}{*}{$\mathrm{Ni}$} & 2019 & $1.53-5.86$ & 2.91 & $3.36 \pm 1.17$ & 2.67 & 4.27 & 34.9 & \multirow{2}{*}{$<0.05$} \\
\hline & 2020 & $2.59-7.35$ & 3.85 & $4.27 \pm 1.27$ & 3.37 & 4.61 & 29.8 & \\
\hline \multirow{2}{*}{$\mathrm{Fe}$} & 2019 & 343-1175 & 579 & $607 \pm 237$ & 446 & 682 & 39.1 & \multirow{2}{*}{$<0.05$} \\
\hline & 2020 & $309-2551$ & 693 & $846 \pm 476$ & 594 & 933 & 56.2 & \\
\hline
\end{tabular}
weight (d.w.)).

Md: median; P90-90 percentile; St. Dev.: standard deviation; CV: coefficient of variance, $p$-values for differences were obtained from Wilcoxon signed-rank test.

According to the Wilcoxon test, no significant differences $(p>0.05)$ were found for $\mathrm{Pb}$ and $\mathrm{Cr}$, while for $\mathrm{Cu}, \mathrm{Cd}, \mathrm{Fe}$, and $\mathrm{Ni}$, significant differences $(p<0.05)$ between the median concentrations were revealed. The $\mathrm{CV}$ values for all elements in both years were less than $75 \%$, which points to the main influence of the regional source of pollution [14]. 
The median values determined in the present study were compared with the data obtained for the previous moss surveys performed in the Moscow region in 2004 and 2014 (Table 2). The content of $\mathrm{Cd}, \mathrm{Cu}$, and $\mathrm{Ni}$ in moss samples was almost at the same level in the period 2004-2020. The higher values of the mean $\mathrm{Pb}$ content in 2019-2020 in comparison with 2014 can be explained by the fact that in 2019-2020 and 2014, the moss samples were collected at different sampling sites: in 2014-in the north-eastern part of Moscow, whereas in 2019-2020 - in places considered to be potentially highly polluted. The iron content was the highest in 2014, followed by 2004, 2020, and 2019, while the content of $\mathrm{Cr}$ in mosses collected in 2019 and 2020 was significantly lower than in 2014 and 2004.

Table 2. Comparison between the median values obtained in the present study and data reported for previous surveys (in $\mathrm{mg} / \mathrm{kg} \mathrm{d.w.).}$

\begin{tabular}{ccccc}
\hline Element & Moscow Region 2020 & Moscow Region 2019 & Moscow Region 2014 [14] & Moscow Region 2004 [13] \\
\hline $\mathrm{Cd}$ & 0.24 & 0.30 & 0.3 & $\mathrm{x}$ \\
$\mathrm{Pb}$ & 4.60 & 4.41 & 0.67 & $\mathrm{x}$ \\
$\mathrm{Cu}$ & 7.76 & 8.98 & 7.1 & $\mathrm{x}$ \\
$\mathrm{Cr}$ & 1.98 & 1.98 & 3.2 & 3.1 \\
$\mathrm{Ni}$ & 3.85 & 2.91 & 3.2 & 2.4 \\
$\mathrm{Fe}$ & 693 & 579 & 1050 & 800 \\
\hline
\end{tabular}

In order to reveal the differences in metal uptake by moss in 2019 and 2020, the element distribution maps of are given in Figure 2. Natural sources of $\mathrm{Cd}$ emissions are volcanic activity and release by vegetation [23]. The main anthropogenic sources are non-ferrous metal production, waste incineration, dust generated during the operation of vehicles, and resuspension of road dust [23,24]. Hjortenkrans et al. [25] showed that emissions from brake linings/tire tread rubber contain a wide range of elements, including $\mathrm{Cd}, \mathrm{Cu}, \mathrm{Pb}, \mathrm{Sb}$, and $\mathrm{Zn}$. Comparing the data obtained in 1998 and 2005, the authors showed that $\mathrm{Cu}$ and $\mathrm{Zn}$ emissions remained unchanged in the studied period, suggesting that brake lining is one of the main sources of these metals. On the other hand, a pronounced decrease in the content of $\mathrm{Pb}$ and $\mathrm{Cd}$ in the studied period was observed. The input of anthropogenic sources of $\mathrm{Cd}$ emission significantly exceeded the release from natural resources. According to the data obtained in 2020, the content of $\mathrm{Cd}$ in the Moscow region diminished by $2-46 \%$. The most pronounced decrease was noticed near the cities of Sergeyev Posad, Solnechnogorsk, and Domodedovo. According to the reports by the national authorities, during the period of self-isolation, traffic in the Moscow region declined by $50 \%$.
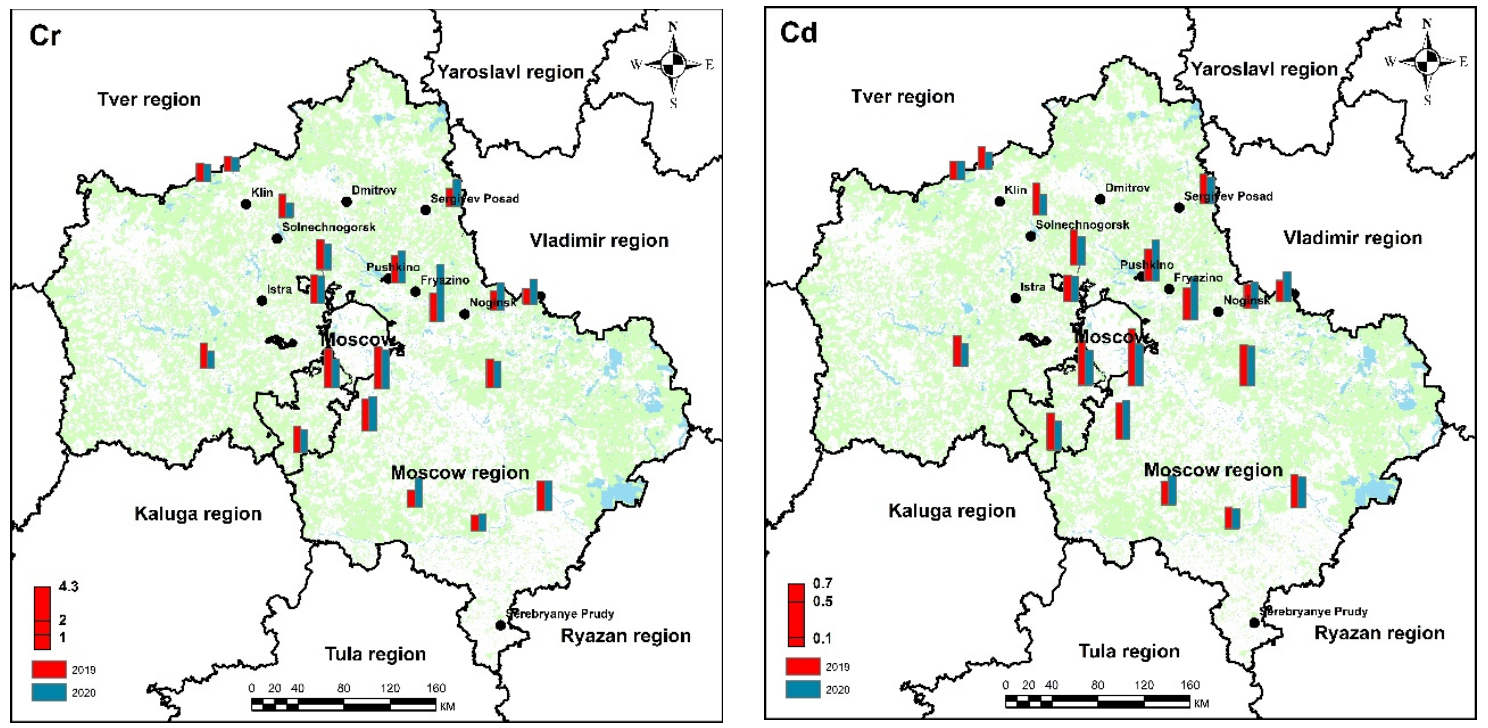

Figure 2. Cont. 


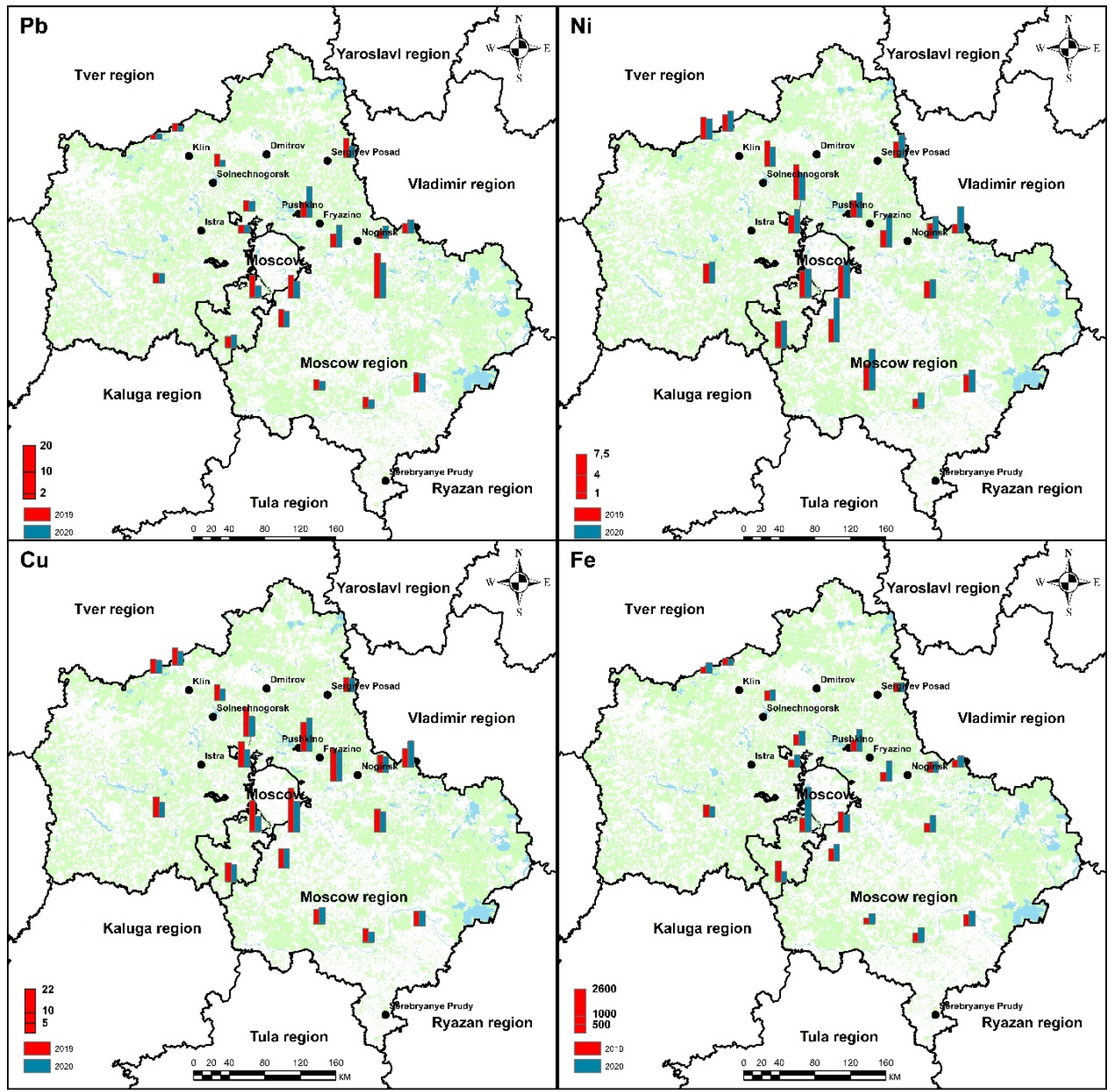

Figure 2. Maps of element content in moss samples collected in 2019 and 2020 in the Moscow region (in $\mathrm{mg} / \mathrm{kg} \mathrm{d.w}$ ).

The increase of $\mathrm{Cd}$ concentrations near Klin and Stupino can be explained by the impact of metallurgical and engineering complexes.

The major sources of $\mathrm{Cr}$ in the environment are metal processing, coal burning, and vehicles. Chromium is one of the most abundant metals in diesel particles [26]. Compared to 2019, in 2020, the content of $\mathrm{Cr}$ in moss samples decreased by 7-35\%, mainly in the north-eastern part of the Moscow region. In Sergeyev Posad, the increase in $\mathrm{Cr}$ content by $59 \%$ may be related to the activities of an engineering plant and the production of paint and coatings. The rise of $\mathrm{Cr}$ content in satellite cities near Moscow by $42-100 \%$ may be associated with the industrial activity of machine-building, metallurgical, and chemical plants, which were operating at full capacity during the self-isolation period.

Brake wear emissions account for up to $75 \%$ of $\mathrm{Cu}$ emissions into the air [27]. A decrease in the $\mathrm{Cu}$ content in moss samples collected in 2020 by $8-50 \%$ compared to the data for 2019 confirms this hypothesis. At the same time, an increase in its content by $38 \%$ in satellite cities near Moscow points to the dominant contribution of industrial activity to $\mathrm{Cu}$ emissions.

The main sources of Fe in the atmosphere are industrial and metallurgical processes, combustion of fossil fuels, transport, as well as resuspension of crustal materials and road dust [28]. In contrast to the previously discussed element, the content of Fe in the moss samples collected in 2020 increased 
significantly in comparison with the data for 2019 . This increase of $3-217 \%$ can be attributed mainly to the resuspension of crustal materials.

Nickel can be released into the atmosphere from natural and anthropogenic sources. The main anthropogenic sources are fossil fuel combustion, smelting of ferrous and non-ferrous metals, waste incineration, and other various sources [29]. The increase in Ni content in satellite cities around Moscow in 2020 may be associated with industrial activities of metallurgical plants in Electrostal, Shchyolkovo, and Podolsk, and engineering plants in Electrostal and Podolsk. The rise of Ni content at other sampling sites is mainly due to vehicles and resuspension of dust particles. In spite of the fact that $\mathrm{Pb}$ content has been declining in many countries due to the introduction of unleaded fuels, vehicles continue to be one of the main sources of $\mathrm{Pb}$ emissions. On a regional scale, industrial activities may contribute to emissions of lead into the air [30]. A significant decrease in $\mathrm{Pb}$ content was noticed in 2020 in comparison with 2019 (up to 48\%), indicating a decline in traffic flow. A considerable increase in $\mathrm{Pb}$ content by $30-65 \%$ in the western part of the Moscow region indicates the dominant role of industrial activity in $\mathrm{Pb}$ emission in this area.

The strength of association of the chemical elements in the moss samples collected in 2019 and 2020 can be seen in Table 3. The Spearman correlation coefficient between 0.5 and 0.7 indicated a good association between the elements, whereas $r$ in the range of $0.7-1.0$ shows strong association of elements [31].

Table 3. Spearman correlation coefficient between element content in mosses collected in Moscow region in 2019 and 2020.

\begin{tabular}{|c|c|c|c|c|c|c|c|}
\hline \multirow{7}{*}{$\stackrel{\circ}{\circ}$} & & $\mathrm{Cd}$ & $\mathrm{Pb}$ & $\mathrm{Cu}$ & $\mathrm{Cr}$ & $\mathbf{N i}$ & $\mathrm{Fe}$ \\
\hline & $\mathrm{Cd}$ & 1.00 & & & & & \\
\hline & $\mathrm{Pb}$ & $0.76^{* *}$ & 1.00 & & & & \\
\hline & $\mathrm{Cu}$ & 0.25 & 0.38 & 1.00 & & & \\
\hline & $\mathrm{Cr}$ & 0.43 & $0.60 * *$ & 0.71 ** & 1.00 & & \\
\hline & $\mathrm{Ni}$ & 0.28 & 0.14 & 0.28 & 0.55 * & 1.00 & \\
\hline & $\mathrm{Fe}$ & $0.56^{*}$ & 0.48 * & $0.46^{*}$ & $0.66^{* *}$ & 0.36 & 1.00 \\
\hline \multirow{7}{*}{ ઠิે } & & $\mathrm{Cd}$ & $\mathrm{Pb}$ & $\mathrm{Cu}$ & $\mathrm{Cr}$ & $\mathrm{Ni}$ & $\mathrm{Fe}$ \\
\hline & $\mathrm{Cd}$ & 1.00 & & & & & \\
\hline & $\mathrm{Pb}$ & $0.55 *$ & 1.00 & & & & \\
\hline & $\mathrm{Cu}$ & 0.36 & $0.74^{* *}$ & 1.00 & & & \\
\hline & $\mathrm{Cr}$ & 0.41 & $0.67^{* *}$ & $0.66^{* *}$ & 1.00 & & \\
\hline & $\mathrm{Ni}$ & 0.42 & 0.39 & $0.61 * *$ & $0.73^{* *}$ & 1.00 & \\
\hline & $\mathrm{Fe}$ & 0.22 & $0.69 * *$ & $0.61 * *$ & $0.71^{* *}$ & 0.40 & 1.00 \\
\hline
\end{tabular}

In 2019, a high positive correlation in $\mathrm{Pb}-\mathrm{Cd}$ and $\mathrm{Cr}$ - $\mathrm{Cu}$ pairs was observed. Road traffic may be responsible for $\mathrm{Cr}, \mathrm{Cu}, \mathrm{Pb}, \mathrm{V}$, and $\mathrm{Zn}$ emissions, whereas fuel combustion is the major source of $\mathrm{Cr}$, $\mathrm{Cu}$, and $\mathrm{V}$ [29]. Good positive correlations were found between $\mathrm{Fe}-\mathrm{Cd}, \mathrm{Cr}-\mathrm{Pb}, \mathrm{Ni}-\mathrm{Cr}$, and $\mathrm{Fe}-\mathrm{Cr}$ pairs of elements, and this may be related to industrial activities. In 2020, a high correlation between $\mathrm{Pb}$ and $\mathrm{Cd}$ was observed again. A high positive correlation was also determined in the $\mathrm{Cu}-\mathrm{Pb}, \mathrm{Ni}-\mathrm{Cr}$, and $\mathrm{Fe}-\mathrm{Cr}$ pairs. Good correlations were obtained between the $\mathrm{Cr}-\mathrm{Pb}, \mathrm{Fe}-\mathrm{Pb}, \mathrm{Ni}-\mathrm{Cu}$, and $\mathrm{Fe}-\mathrm{Cu}$ pairs of elements. The obtained associations indicate a possible anthropogenic influence in the study area; however, their source could be a resuspension of soil particles.

The use of geochemical indices is important for the assessment of the contamination status of the investigated territory [32]. In the present study, the contamination factor (CF), Geo-accumulation Index ( $\mathrm{I}_{\text {geo }}$ ), and pollution load index (PLI) were calculated [14,32] (Table 4). In 2019, no contamination with $\mathrm{Ni}$ and moderate contamination with $\mathrm{Cr}, \mathrm{Fe}$, and $\mathrm{Cu}$ were determined. The $\mathrm{CF}$ values for $\mathrm{Cd}$ and $\mathrm{Pb}$ were higher than 3.0 and indicated considerable contamination. The situation changed in 2020 when $\mathrm{CF}$ pointed to moderate pollution for all elements. The decrease of $\mathrm{CF}$ values for $\mathrm{Pb}$ and $\mathrm{Cd}$ may 
be associated with the reduction of traffic flow, while the impact of the industrial activity remained at the same level. The $I_{g e o}$ results indicate that mosses were uncontaminated to moderately contaminated with the determined elements. In 2019, the moss samples were moderately contaminated with $\mathrm{Cd}, \mathrm{Pb}$, $\mathrm{Cu}$, and $\mathrm{Fe}$, and in 2020, with $\mathrm{Cd}$ and $\mathrm{Pb}$.

Table 4. Mean values of the contamination factor CF and Geo-accumulation Index Igeo for the studied area.

\begin{tabular}{cccccc}
\hline & \multicolumn{2}{c}{ CF } & \multicolumn{2}{c}{ Igeo } \\
\hline & Year & 2019 & $\mathbf{2 0 2 0}$ & $\mathbf{2 0 1 9}$ & $\mathbf{2 0 2 0}$ \\
\hline Element & & & & \\
\hline $\mathrm{Cd}$ & 3.06 & 1.85 & 0.91 & 0.24 \\
$\mathrm{~Pb}$ & 3.28 & 2.96 & 0.93 & 0.77 \\
$\mathrm{Cu}$ & 1.61 & 1.49 & 0.01 & -0.09 \\
$\mathrm{Cr}$ & 1.39 & 1.58 & -0.17 & -0.02 \\
$\mathrm{Ni}$ & 0.92 & 1.30 & -0.79 & -0.26 \\
$\mathrm{Fe}$ & 1.74 & 1.48 & 0.12 & -0.17 \\
\hline
\end{tabular}

A PLI below 1.0 shows that elemental loads are approximately equal to the background level, and values above 1.0 indicate the degree of pollution [33]. As can be seen from the maps presented in Figure 3, in 2019, the entire territory under investigation belongs to the moderately polluted to unpolluted category (except for the sites near Troitsk and Domodedovo, which are moderately polluted). Similarly, in 2020, the sampling territory can be characterized as moderately polluted to unpolluted. The PLI values were higher than 2.0 near Domodedovo and Staraya Kupavna.
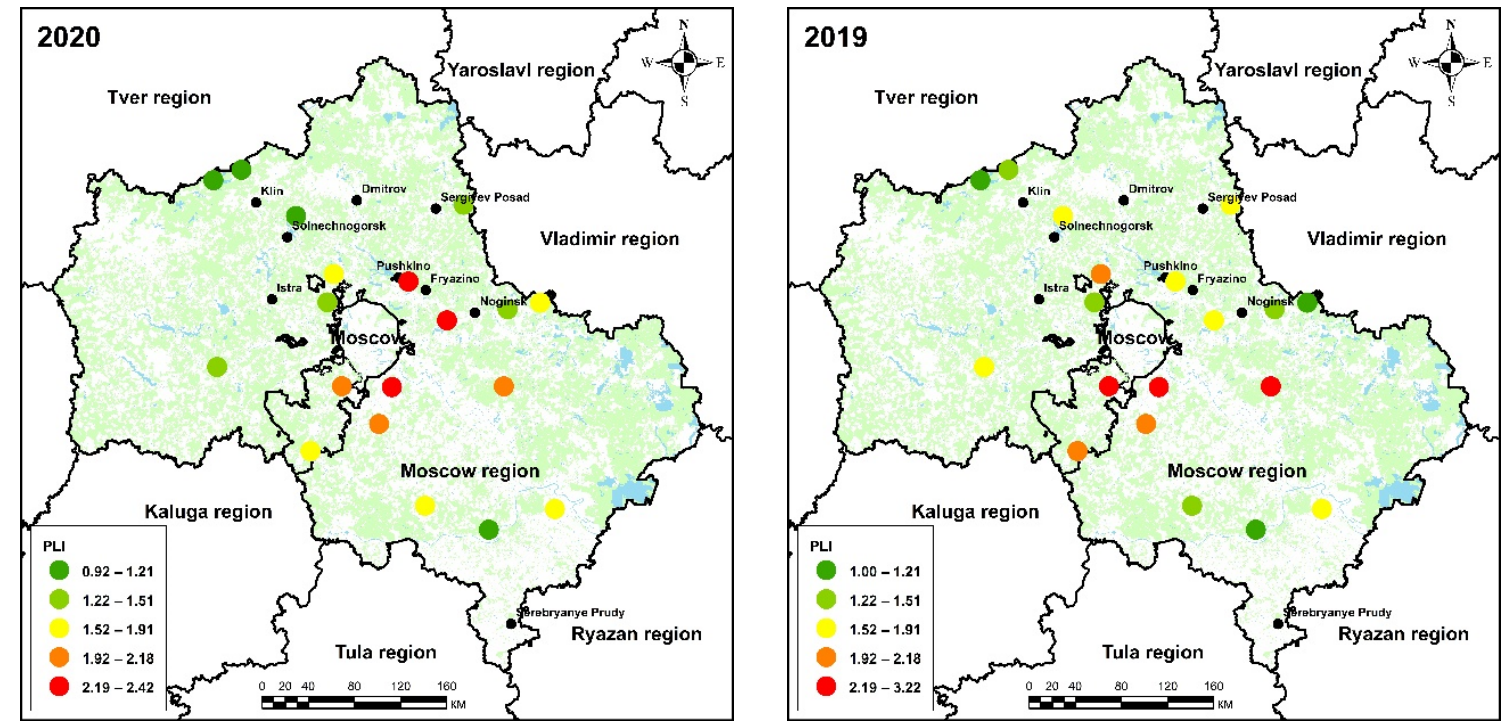

Figure 3. The map of the distribution of PLI values in Moscow region.

\section{Conclusions}

The results from two biomonitoring studies performed in the Moscow region in 2019 and 2020 were compared. Moss sampling has proven to be to be a suitable and low-cost indicator of heavy metal air pollution. The self-isolation period adopted to cope with the COVID-19 pandemic resulted in a decrease in $\mathrm{Cd}$ content in the Moscow region, while the content of other analyzed elements decreased in the north-eastern part of the Moscow region and remained the same or even increased in satellite cities near Moscow. Owing to the decline in the flow of traffic, stationary sources can be considered the primary source of metal emission into the atmosphere. In 2019 and 2020, according to the PLI values, the territory of the Moscow region was characterized as moderately polluted to unpolluted. 
Author Contributions: Conceptualization, all authors; methodology, N.Y., I.Z., D.G., K.V., software, O.C.; formal analysis, all authors; writing — original draft preparation, I.Z.; writing-review and editing, all authors. All authors have read and agreed to the published version of the manuscript.

Funding: This research received no external funding.

Conflicts of Interest: The authors declare no conflict of interest.

\section{References}

1. WHO Archived: WHO Timeline-COVID-19. Available online: https://www.who.int/news-room/detail/2704-2020-who-timeline---covid-19 (accessed on 23 July 2020).

2. Ma, C.J.; Kang, G.U. Air quality variation in wuhan, daegu, and tokyo during the explosive outbreak of covid-19 and its health effects. Int. J. Environ. Res. Public Health 2020, 17, 4119. [CrossRef]

3. Nadzir, M.S.M.; Ooi, M.C.G.; Alhasa, K.M.; Bakar, M.A.A.; Mohtar, A.A.A.; Nor, M.F.F.M.; Latif, M.T.; Hamid, H.H.A.; Ali, S.H.M.; Ariff, N.M.; et al. The impact of movement control order (MCO) during pandemic COVID-19 on local air quality in an urban area of Klang valley, Malaysia. Aerosol Air Qual. Res. 2020, 20, 1237-1248. [CrossRef]

4. Safarian, S.; Unnthorsson, R.; Richter, C. Effect of Coronavirus Disease 2019 on CO2 Emission in the World. Aerosol Air Qual. Res. 2020, 20, 1197-1203. [CrossRef]

5. Zhang, J.; Cui, K.; Wang, Y.-F.; Wu, J.-L.; Huang, W.-S.; Wan, S.; Xu, K. Temporal Variations in the Air Quality Index and the Impact of the COVID-19 Event on Air Quality in Western China. Aerosol Air Qual. Res. 2020, 20, 1552-1568. [CrossRef]

6. Xu, K.; Cui, K.; Young, L.H.; Hsieh, Y.K.; Wang, Y.F.; Zhang, J.; Wan, S. Impact of the COVID-19 event on air quality in central China. Aerosol Air Qual. Res. 2020, 20, 915-929. [CrossRef]

7. Kaskun, S. The effect of COVID-19 pandemic on air quality caused by tra c in Istanbul. Res. Sq. 2020, 1-24. [CrossRef]

8. Siciliano, B.; Carvalho, G.; da Silva, C.M.; Arbilla, G. The Impact of COVID-19 Partial Lockdown on Primary Pollutant Concentrations in the Atmosphere of Rio de Janeiro and São Paulo Megacities (Brazil). Bull. Environ. Contam. Toxicol. 2020, 105, 2-8. [CrossRef]

9. Lequy, E.; Siemiatycki, J.; Leblond, S.; Meyer, C.; Zhivin, S.; Vienneau, D.; de Hoogh, K.; Goldberg, M.; Zins, M.; Jacquemin, B. Long-term exposure to atmospheric metals assessed by mosses and mortality in France. Environ. Int. 2019, 129, 145-153. [CrossRef]

10. Markert, B.A.; Breure, A.M.; Zechmeister, H.G. Chapter 1 Definitions, strategies and principles for bioindication/biomonitoring of the environment. Trace Met. Contam. Environ. 2003, 6, 3-39. [CrossRef]

11. Harmens, H.; Ilyin, I.; Mills, G.; Aboal, J.R.; Alber, R.; Blum, O.; Coşkun, M.; De Temmerman, L.; Fernández, J.A.; Figueira, R.; et al. Country-specific correlations across Europe between modelled atmospheric cadmium and lead deposition and concentrations in mosses. Environ. Pollut. 2012, 166, 1-9. [CrossRef]

12. Harmens, H.; Norris, D.A.; Steinnes, E.; Kubin, E.; Piispanen, J.; Alber, R.; Aleksiayenak, Y.; Blum, O.; Coşkun, M.; Dam, M.; et al. Mosses as biomonitors of atmospheric heavy metal deposition: Spatial patterns and temporal trends in Europe. Environ. Pollut. 2010, 158, 3144-3156. [CrossRef] [PubMed]

13. Vergel, K.N.; Frontasyeva, M.V.; Kamanina, I.Z.; Pavlov, S.S. Biomonitoring of heavy metals in the northeast of the Moscow region using moss-biomonitors. Ecol. Urban. Territ. 2009, 3, 88-95. (In Russian)

14. Vergel, K.; Zinicovscaia, I.; Yushin, N.; Frontasyeva, M.V. Heavy Metal Atmospheric Deposition Study in Moscow Region, Russia. Bull. Environ. Contam. Toxicol. 2019, 103, 435-440. [CrossRef]

15. Subregions, W.; Pulsipher, A. World Regional Geography Atlas; W.H. Freeman \& Co.: New York, NY, USA, 2014.

16. Spranger, T. Manual on Methodologies and Criteria for Modelling and Mapping Critical Loads E Levels and Air Pollution Effects, Risks and Trends; Umweltbundesamt: Dessau-Roßlau, Germany, 2004.

17. Wilcoxon, F. Individual Comparisons by Ranking Methods. Biom. Bull. 1945, 1, 80. [CrossRef]

18. Gonçalves, E.P.R.; Boaventura, R.A.R.; Mouvet, C. Sediments and aquatic mosses as pollution indicators for heavy metals in the Ave river basin (Portugal). Sci. Total Environ. 1992, 114, 7-24. [CrossRef]

19. Fernández, J.A.; Carballeira, A. Evaluation of contamination, by different elements, in terrestrial mosses. Arch. Environ. Contam. Toxicol. 2001, 40, 461-468. [CrossRef] 
20. Okedeyi, O.O.; Dube, S.; Awofolu, O.R.; Nindi, M.M. Assessing the enrichment of heavy metals in surface soil and plant (Digitaria eriantha) around coal-fired power plants in South Africa. Environ. Sci. Pollut. Res. 2014, 21, 4686-4696. [CrossRef]

21. Müller, G. Index of geoaccumulation in sediments of the Rhine River. Geol. J. 1969, 2, 108-118.

22. Jorfi, S.; Maleki, R.; Jaafarzadeh, N.; Ahmadi, M. Pollution load index for heavy metals in Mian-Ab plain soil, Khuzestan, Iran. Data Br. 2017, 15, 584-590. [CrossRef] [PubMed]

23. Williams, C.R.; Harrison, R.M. Cadmium in the atmosphere. Experientia 1984, 40, 29-36. [CrossRef]

24. Adamiec, E.; Jarosz-Krzemińska, E.; Wieszała, R. Heavy metals from non-exhaust vehicle emissions in urban and motorway road dusts. Environ. Monit. Assess. 2016, 188, 369. [CrossRef] [PubMed]

25. Hjortenkrans, D.S.T.; Bergbäck, B.G.; Häggerud, A.V. Metal emissions from brake linings and tires: Case studies of Stockholm, Sweden 1995/1998 and 2005. Environ. Sci. Technol. 2007, 41, 5224-5230. [CrossRef]

26. Denier van der Gon, H.A.C.; Hulskotte, J.H.J.; Visschedijk, A.J.H.; Schaap, M. A revised estimate of copper emissions from road transport in UNECE-Europe and its impact on predicted copper concentrations. Atmos. Environ. 2007, 41, 8697-8710. [CrossRef]

27. Yu, C.H.; Huang, L.; Shin, J.Y.; Artigas, F.; Fan, Z.H.T. Characterization of concentration, particle size distribution, and contributing factors to ambient hexavalent chromium in an area with multiple emission sources. Atmos. Environ. 2014, 94, 701-708. [CrossRef] [PubMed]

28. Sanderson, P.; Su, S.S.; Chang, I.T.H.; Delgado Saborit, J.M.; Kepaptsoglou, D.M.; Weber, R.J.M.; Harrison, R.M. Characterisation of iron-rich atmospheric submicrometre particles in the roadside environment. Atmos. Environ. 2016, 140, 167-175. [CrossRef]

29. Tian, H.Z.; Lu, L.; Cheng, K.; Hao, J.M.; Zhao, D.; Wang, Y.; Jia, W.X.; Qiu, P.P. Anthropogenic atmospheric nickel emissions and its distribution characteristics in China. Sci. Total Environ. 2012, 417-418, 148-157. [CrossRef]

30. Wong, G.W.K. Air pollution and health. Lancet Respir. Med. 2014, 2, 8-9. [CrossRef]

31. Barandovski, L.; Frontasyeva, M.V.; Stafilov, T.; Šajn, R.; Ostrovnaya, T.M. Multi-element atmospheric deposition in Macedonia studied by the moss biomonitoring technique. Environ. Sci. Pollut. Res. 2015, 22, 16077-16097. [CrossRef]

32. Rutkowski, P.; Diatta, J.; Konatowska, M.; Andrzejewska, A.; Tyburski, Ł.; Przybylski, P. Geochemical referencing of natural forest contamination in Poland. Forests 2020, 11, 157. [CrossRef]

33. Salo, H.; Bućko, M.S.; Vaahtovuo, E.; Limo, J.; Mäkinen, J.; Pesonen, L.J. Biomonitoring of air pollution in SW Finland by magnetic and chemical measurements of moss bags and lichens. J. Geochem. Explor. 2012, 115, 69-81. [CrossRef]

Publisher's Note: MDPI stays neutral with regard to jurisdictional claims in published maps and institutional affiliations.

(C) 2020 by the authors. Licensee MDPI, Basel, Switzerland. This article is an open access article distributed under the terms and conditions of the Creative Commons Attribution (CC BY) license (http://creativecommons.org/licenses/by/4.0/). 